\title{
Multinational Corporations: Corporate Social Responsibility versus Environmental Problems
}

\author{
MicheloChilwalo, MSW \\ University of Zambia, Zambia
}

doi: 10.19044/esj.2016.v12n17p241 URL:http://dx.doi.org/10.19044/esj.2016.v12n17p241

\begin{abstract}
Corporate Social Responsibility (CSR) is a subject of major concern and discussion in today's world. The need for the local people to benefit from their resources is a noble gesture, which those involved in extracting their resources should uphold if poverty is to be addressed among millions affected by the scourge. This paper aimed to understand Multinational Corporation's (MNCs) role in promoting CSRvis-à-visenvironmental problems arising from their operations in selected parts of the world. The study mainly generated and used qualitative data through desk review of literature on MNCs involved in agriculture, logging, pharmaceuticals and extractive industries such as minerals, gas and oil. The study revealed that hitherto, local people's needs have remained unheededby MNCs, their rights are being violated and their environments have undergone irreparable damages. The realisation of all human rights: civil and political rights, social, economic and cultural rights, and the collective-developmental rights, the right to the clean environment, which every nation involved in any economic activity should achieve have been elusive in communities which are richly endowed with natural resources at the expense of profit maximisation by the MNCs in a bid to further enhance their economic might. This has resulted in massive suffering for the locals where MNCs operate or have abandoned their activities after depleting the resources without leaving any tangible infrastructure such as clinics, schools, roads, recreation facilities, and piped water.
\end{abstract}

Keywords: Multinational Corporation (MNCs), Corporate Social Responsibility (CSR), Environmental problems, Human rights

\section{Background}

Logging companies felling old growth forests in Australia, Indonesia, Africa and South America and clearing whole mountains in Canada; oil tanker spillages; over-fishing to the point that some species have become 
extinct; polluting technologies in use in manufacturing-all areas of concern that, due to the interconnectedness of the eco-system, affect the whole world (Dobscha and Ozanne, 2001). As the demand for natural resources has increased in this globalised world due to burgeoning population, so have the MNCs increased their spheres of operation in a bid to assuage their insatiable hunger. The need to maximise profits and continue to increase their spheres of influence has seen them in almost all the continents of the world where they can extract resources. The pressure to increase market and acquire higher level of resources such as minerals and petroleum drive U.S and European corporations to transnational expansion primarily to Latin America, Asia, Africa and Middle East (Korten, 2001). As the corporations business grow significantly, the environment and the local people where they operate continue to bear the heaviest brunt since corporations rarely invest in these areas, and where they have done so it has been on a minute scale.

The business dictionary defines Multinational Corporation (MNC) as anenterpriseoperating in several countries but managed from one (home) country. Generally, any company or group that derives a quarter of its revenue from operations outside of its home country is considered a MNC. There are four categories of MNC: (1) a multinational, decentralized corporation with strong home country presence, (2) a global, centralised corporation that acquires cost advantage through centralised production wherever cheaper resources are available, (3) an international, company that builds on the parents corporation technology or Research and Development (R\&D), or (4) a transnational enterprise that combines the previous three approaches (Business Dictionary, 2016).

The World Business Council for Sustainable Development (2000) defines Corporate Social Responsibility (CSR) as 'the commitment of business to contribute to sustainable economic development, working with employees, their families, the local community and society at large to improve their quality of life'. The European Commission's Green Paper 'Promoting a European Framework for Corporate Social Responsibility' (July 2001) as cited in Cowe (2001) notes that CSR means not only fulfilling legal expectations, but also going beyond compliance and investing 'more' into human capital, the environment and relations with stakeholders. Thus, companies should uphold human dignity to improve the welfare of people through provision of educational and social programmes, reduction of waste and pollution on the environment and be able to consider local people views on issues affecting them in various facets of life. Central to this is the need to realize social inclusion,participation, empowerment and social justice through equitable distribution of resources among the local people from the proceeds realized through the operations of MNCs. 
Environmental problems are, 'known processes (such as resourceconsumption) that have negative effects on the sustainability of the environmental quality necessary for the wellbeing of the organisms living in it' (Business Dictionary, 2016). Environmental problems emanating from MNCs operations include polluting rivers with toxic materials, inundations, incessant noise, dust, creating trenches which act as breeding ground for mosquitoes and death traps for children, among others.

\section{Overarching question}

- Why have MNCs found it difficult to provide corporate social responsibility (CSR) and protect the environment?

\section{Specific questions}

- Are there substantial links between MNCs operations and environmental problems?

- $\quad$ Is there empirical evidence to justify the link between environmental destruction and MNCs need for profit maximization?

- Is there empirical evidence that buttress International Economic Institution and developed countries influencing MNCs to exploit the environment?

- Is there empirical evidence to support the claim of environmental destruction by MNCs and lack of corporate social responsibility?

\section{Methodology}

This was desk review study which mainly generated and used qualitative data from various literature sources on MNCs involved in agriculture, logging pharmaceuticals and extractive industries such as minerals, and oil. To capture as many relevant citations as possible, a wide range of MNCs corporate social responsibilities (CSR) and environmental problems databases were searched to identify the relevant information, mainly from peer reviewed articles. Furthermore, various internet engines were searched for web pages that could provide references using the key words: MNCs, CSR and environmental problem. In this way selected studies provided information on MNCs in relation to CSR and environmental problems. Empirical evidence on the operations of MNCS and case studies from various parts of the world to buttress the argument under scrutiny have been discussed.

\section{Data analysis}

Secondary analysis of qualitative data is the use of existing data to find answers to research questions that differ from the questions asked in the original research (Hinds, Vogel and Clarke-Steffen, 1997). Barney Glaser 
(1963) suggested that secondary analysis carried out by an independent researcher could, among other things, 'lend new strength to the body of fundamental social knowledge'. Authors have applied secondary analysis to data when they have wanted to: pursue interests distinct to those of the original analysis (Hinds et al., 1997); apply a new perspective or a new conceptual focus to the original research issues (Heaton, 1998). Furthermore, secondary analysis may be of benefit in situations where the topic being discussed is a sensitive one and participants may be what Fielding (2004) has called an 'elusive population', one that is difficult to access. After having spent some time reading and understanding the data, the author was impressed by the sheer amount of published work on MNCs in relation to CRS and environmental problems. However, not all information was relevant to address the research questions. From all the available articles and other secondary sources, data was later extracted to generate themes and patterns to address the research questions.

\section{Results and discussion}

\section{MNCs expansion and effects on the environment}

The nexus between environmental problems and development is not one of recent origin. In ancient times, Plato was concerned about environmental degradation as witnessed by his complaints in the Critas. He said the environment has been turned into 'bones of a wasted body...richer and softer parts of the soil having fallen away, and the mere skeleton being left' (Clark 1986, p. 335). At no time in human history has the problems affecting the environment reached unprecedented levels than today. With the opening up of trade globally, MNCs have continued to aggrandise their operation through massive resource exploitation which has further continued to debilitate the state of the environment. The sole aim is to maximize profit and get the bigger return as much as they can. Corporate social responsibility more often than not, is not on their agenda.

A surfeit of literature affirms that MNCs have less interest to invest in human capital, environmental protection and the community in which they operate. One of the reasons for this is their perpetual relocation from one part of the globe to another which is heavily influenced by profits, regulations and a host of other consideration that favour their operations. This has made them become wealthier. Kelleher (2005) argues that large corporations are becoming increasingly more remote from society and that the dollar is the only consideration for decision making. Social responsibility is reduced to a revenue-enhancing marketing ploy to be produced like a rabbit out of a hat when needed. For instance, 51 of the largest 100 economies in the world are corporations and that the number of countries in this group is steadily declining. Of these 51, 20 are from USA, 20 are from Asia (primarily Japan), 
10 are European, and 1 is owned jointly by European/US investors (Suzuki, 1999).

However, in recent years this traditional establishment has been shifting. There has been an increase in the number of MNCs enterprises from outside the traditional triad (Japan, North America and Western Europe). More and more, companies from the former periphery are expanding. As of 2013, five of the top twenty largest global companies as established within the FT Global 500 are based outside the triad, most notably from China (4: Petro China, 11: ICBC, 14: China Mobile, 19: China Construction Bank) and from South-Korea (13: Samsung). Other non-triad multinational enterprises (NTMNEs) within the top 200 come from Brazil (Ambev, No. 41), Russia (Gazprom, No. 57), Taiwan (Taiwan Semiconductor Manufacturing, No. 70), Saudi Arabia (Saudi Basic Industries, No. 83), India (Tata, No. 134), Mexico (AMX, No. 144) or from Singapore (Singapore Telecom, No. 170). Many of these companies have expanded immensely over the last years, also reflected by the fact that there are nine NTMNE newcomers on the list, mainly from China, but also from Indonesia, Thailand and Turkey, bringing the total number of non-triad companies in the 2013 FT Top 500 to 121(Cissé, Grimm and Nölke, 2014). From this, it can be argued that if these corporations are to continue to dominate and accumulate their profits, they have to exploit massively not only the environment, in which they operate, but also the workers, families and the communities at large.

Though the dire consequences of MNCs have been in almost in all their areas of operations, the severe brunt of their environmental problems and their lack on CRS have been heavily felt in developing countries. The strong desire for developing countries to attract Foreign Direct Investment (FDI) as a way to address high poverty levels coupled with lack of enforcement of environmental laws have made MNCs to flout established law.The operations of MNCs in underdeveloped countries involve the use of hazardous materials, extraction of natural resource base, environmental degradation, and the spread of toxic materials, emission of noxious gases, which pose immediate and long term risks to the masses (Baram, 1994). In a period of four years, from 1976 to 1980, about 800 incidents of oil spillage were reported in the Niger Delta in Ogoniland in Nigeria, and from 1980 to 1990, about 2,000 incidents occurred. From 1990 to 1995, about 710 other cases of spillage were said to have occurred. In all, from 1976 to 1995, there were more than 3,500 incidents of oil spillage, resulting in the discharge of more than 2 million barrels of crude oil into the land, swamps, and offshore environments (Petroleum News,1998, p. 1). The activities of the MNC have brought severe problems to the environment. The need to reverse this trend is compromised by the profits associated with their business deals across the globe. Harper (1996, p. 373) described the environmental impact of MNCs 
as: 'MNCs have orchestrated the cutting of rain forests in Indonesia and Malaysia. Similar ecological degradation, ecocide, and genocide associated with Multinational Oil Companies in Nigeria, Texaco made a tremendous devastation in the Ecuadorian rainforest, where it dominated the nation's oil industry for over 20 years'. As a result of this irreparable damage which is being inflicted on both the natural fauna and flora, which includes aquatic and terrestrial, the ecosystem has been massively impaired. Thus, the local people are left in a precarious situation when the MNCs leave their area. They lose their precious resources, which in most cases is their main source of livelihood without receiving any benefit to be proud of in future. Arising from this lack of CSR by many MNCs has been increasing pressure for corporations to adopt more responsible business by NGOs, the media, and private citizens in the USA, Britain, Canada, Japan, German and Australia (Greenpeace, 2003).

MNCs operations have also caused fatal deaths to humans, aquatic and terrestrial animals. Their lack of ethical considerations has brought them under ridicule. For instance, the most infamous incidents of pesticide poisoning involved the banned pesticide exported from the U.S. to Egypt in the 1970s. The use of this product was linked to illness and deaths among the people and over 1,000 deaths of water buffalo. Mass poisoning has also been found in Ecuador, Iraq, and several African countries (Scherr, 1987). Adherence to CSR enables the company to be cognizant of the end results of their product. What will be the effects on the natural environment, human and animal life? In other words, product stewardship is cornerstone when it comes to CSR of the company. 'Product stewardship encompasses business responsibility to inform consumers about what product contain (type of material, source etc.) their proper use and disposal, and social and environmental impact of the whole product life cycle' (Cowe, 2001, p. 48). It can be argued that most MNCs do not adhere to this pertinent issue which could have enhanced their image in areas where they do business. Harper (1996) writes that 'at their outrageous worst MNCs have promoted and sold pharmaceuticals, pesticides, baby formulas, and contraceptives already banned or restricted as unsafe in their home countries in the Third World ...they have brokered the sale of toxic wastes to poor nations... shipment of toxic industrial and medical wastes to Africa which subsequently affect the environment'.

In countries where stringent measures are instituted on environmental laws and regulations, flouting of laws is minimal and in some places hardly exists at all. Tan and Wang(2011)assert that over the past several decades, some MNCs have capitalized on China's bureaucratic fragmentation to use the Chinese market as a place to dump products that would be considered inferior or outdated in their home countries. This strategy has resulted in 
distrust and grievances among many Chinese nationals. However, as China's bureaucracy becomes more aligned, such dumping strategies are increasingly becoming out of favour. Thus, compelling MNCs to align their operations to national and international standards of environmental protection lessens the damages on the environment that are currently being overlooked at the expense of profit maximisation in many parts of the world. MNCs need to be compelled to follow established laid down guidelines and should be criticised in order for them to conform to the needs of local people. Without such criticism, millions of local people will continue to suffer while their resources are being exploited to enrich only a few who in most cases do not care about environmental degradation, human rights violation, let alone investing in human capital.

A stark contrast between what China promotes at home and their activities in Africa is evident and has been documented. In Africa, many examples illustrate the environmental impacts linked to Chinese MNCs investments in extractive industries. In Gabon, Chinese oil company, SINOPEC, operating in the oil industry in Loango National Park was ordered to stop its exploration project in September 2006. The Gabonese ministry of environment did not approve the environmental impact study and oil exploration in the park which threatened animals (Bosshard, 2008). In Zambia, in 2013 the government urged to close down Chinese mining company Collum Coal Mine, in Sinazongwe district for establishing low standard working conditions and failing to implement environmental and safety regulations.A few months after reopening the mine, 50 families were forced to relocate because the huge cracks opened in the walls of their houses forcing them to leave their belongings including livestock. The reason for the sudden collapse was weak pillars in the tunnels of the mine situates below the houses. The mine did not assess the impact that the tunnels would have on the surrounding population (Financing Finance, 2016). Despite continued poor safety, health and environmental records hitherto, the company was repeatedly warned by the Zambian government to conform to the mining required standards.

Due to these complaints about and questions around the environmental impact of Chinese investments in Africa, African governments (Sierra Leone, Democratic Republic of Congo (DRC), Zambia) are becoming more assertive in dealing with Chinese companies about environmental standards and corporate social responsibility. Following criticism and complaints on environmental pollution and poor safety standards a number of Chinese projects in extractive industries (oil, mining, copper, coal and so on) in Africa have been closed (Mol, 2011). 


\section{How international economic institutions (IEI) and developed countries have influenced MNCs to exploit the environment}

Environmental problems arising from MNCs operations have also been fuelled by the acts of large multilateral institutions such as the World Banks and International Monetary Fund (IMF) and the home governments of the MNCs. For instance, in his 1991 memo, Dr. Lawrence Summers the then Chief Economist of the World Bank postulated the unbridled market approach for MNCs environmental damage in less developed countries. The Boston Globewriters suggested in March 2001, as others apparently had previously, that the memo was actually written by another economist, Lant Pritchett, but it was signed and circulated at the World Bank under Summers’ name (Healy and Donnelly 2001 as cited in Johnson, Pecquet, and Taylor, 2007). The memo dated 12 December 1991 was prepared for use by the Bank while preparations were underway for the United Nations conference for Environment and Development, held in Rio de Janeiro in June 1992. This memo was later leaked to the environmental community.In his memo Summers argued that, 'Dirty' Industries: Just between you and me, shouldn't the World Bank be 'encouraging MORE migration of the dirty industries to LDCs (Less Developed Countries)? I can think of three reasons:...' (http://www.whirledbank.org/ourwords/summers.htmlaccessed on 14/04/2016). Summer (1991) is also noted of having said that, human lives in LDC are of lesser value relative to human lives in the developed nations. This implies is that, regardless of the dire consequences environmental problems may inflict on peoples of LDC by these companies, it will have less value.It is this egoistic attitude, that most MNCs do not place premium on CSR in their operations especially in the LDC. Issues of environmental protection are secondary since profits maximization tends to supersede any consideration.

In like manner, Addo (1999) notes that MNCs tremendously benefits from the doctrine of neo-liberal economics as well as the 'home and host' state quagmire, which combines with limited liability and decentralised decision-making to allow for double standards in human rights promotion to take place internationally. Furthermore, the policies of the International Economic Institutions (IEIs) such as the International Monetary Fund (IMF), World Bank, and the World Trade Organization (WTO), have allowed the MNCs to gain a position of considerable influence on the Economic, Social and Cultural Rights (ESCR) agendas of nation states. Such powerful institutions should advocate for protecting poor countries through social responsibility by MNCs in lieu of worsening their conditions of living. It is for this reason that some scholars have put these IEI on the spotlight. Korten (1997) vehemently writes that, 'We should start by dismantling the World Bank, the International Monetary Fund, the General Agreement on Traffic 
and Trade and the World Trade Organisation. These institutions exist to advance the interests of the global corporations and financial institutions at the expense of the national, community and human interest. We should prohibit any form of involvement by corporations, especially foreign and global corporations, in policy making of international agencies and in national and local politics'.

Kelleher (2005) posits that corporations are not to be trusted simply because they exist to make profits. They do not act in the best interest of the broader community unless there is a good return on their investment. They have manifested this attribute by leaving when the economic environment is not in their favour. Anglo America can be a case in point when they pulled out of Zambia's Konkola Copper Mine (KCM) due to plummeting copper prices in 2002. This act resulted in massive job losses, uncertainties, and tremendously affected the Zambian economy which hitherto has continued to rely heavily on the mining sector since colonial times.

Developed countries have been on the fore in manipulating the environmental treaties so that MNCs can continue to plunder natural resources especially in developing countries without facing the wrath of the law both in host countries where they operate and at a global level. Darimani (2005) asserts that the Canadian government has been very instrumental in influencing regional and national policies for Africa. During the process leading to the World Summit on Sustainable Development (WSSD) the Canadian government played a role in re-writing the section of the WSSD outcome on Mining, Minerals and Metals. The revised text which was officially adopted in Johannesburg, South Africa clearly diminishes issues of regulation, obligation and rights. This very act has further enhanced the corporations' need to maximise profits without investing in the communities they extract resources. In recent years there has been a proliferation of MNCs in developing countries that have continued to ignore and violate the rights of the locals and investing in environmental protection which further debilitate the state of the ecosystem. Dauvergne (1997) reports that the degree to which Asian governments value economic growth over environmental concern can be seen in their preferential treatment of MNCs, despite studies highlighting cases of exploitation and unsustainable practices. One of the examples is the role of Japanese MNCs in forest, wood pulp and other wood related products.

\section{Selected case studies}

This section cites some case studies to buttress the argument on how MNCs reap resources without due consideration on the Economic, Social and Cultural Rights (ESCR) of the local people in which they operate. Case studies from Ghana, Zambia, Nigeria and Indonesia are discussed at length. 


\section{The Bonte case}

In Ghana, two Canadian mining corporations namely Bonte Gold Mines Company and Golden Star Resources have wantonly exploited the environment without the community benefiting significantly from any of the proceeds. Bonte owned and operated a 30 year lease of alluvial mine along river Bonte at Bonteso in the Ashanti region of Ghana. Darimani (2005) reports that the company operated for 15 years until 2005 when it came under liquidation. The company closed without reclaiming the environment. An area over 8 kilometers has been degraded by the activities of the company. The area is now littered with hills of hipped stones and sand interspersed with settling ponds. The ponds are now breeding ground for mosquitoes and waterborne diseases. Hills of heaped stones and sand not only impede vegetation from regeneration but also prevent local communities from using the area for farming. It is for this reason that Wimberly (1990) indicates that 'MNCs distort development in the Third World by retarding economic growth, promoting economic injustice, obstructing domestic political processes that may be contrary to core economic or ideological interests; and they also distort development by diverting land from sustainable production for domestic needs and by displacing poor farmers and indigenous landholders who have little or no alternative means of livelihood' (p. 76).

Furthermore, farmers affected by the operations of the company have not been compensated for their destroyed farms and land acquired for the mines. These acts clearly illuminate the lack of corporate social responsibility on the side of the mine. This has adversely affected the state of the environment in the area which could have been lessened if CSR was on the agenda of the mining company. Kelleher (2005) affirms that the right thing for corporations is about being honest, having ethical practices, forging mutually beneficial partnerships with communities, taking a stewardship role with the natural environment, and being socially and culturally responsible and respectful. In this respect MNC need to invest in the communities so that communities should enjoy the benefits realized from the natural resources on which they sit since natural resources are finite in nature.

In this globalised world the trend to reinvest resources by MNCs in communities is slowly subsiding. Darimani (2005) asserts that the communities have not benefited from any social responsibility project executed by the company. For the entire 15 years of the operation of Bonte Gold Mine Limited did not provide a clinic, a school block or open up a road for the any of the communities near its concession. Gurr (1993) also notes that the global trend of industrialization, economic expansion, and globalisation resting on increased exploitation of natural resources, have mostly been at the expense of communal groups. Mention should be made 
that the trend to exploit locals has also been aggravated by weak policies and institutional frameworks in most least developed countries in a bid to attract Foreign Direct Investment (FDI) which is currently being perceived as an engine for economic growth. Unfortunately, the perceived FDI has not translated to improve the welfare of the people, with millions still mired in poverty. A dichotomy still manifestsin most countries, especially in LDCs between high investments flows, high poverty level and environmental degradation.

\section{Konkola case}

Mining has been the mainstay of the Zambian economy from the time of the British colonial reign. Hitherto, the mining sector continues to contribute significantly to the nation's Gross Domestic Product (GDP). Alarmingly though, poverty still haunt the majority of the Zambians who are still wallowing in squalid conditions. Copper which is a finite resource should be extracted in such a way that ordinary Zambians will continue to enjoy from the proceeds being generated for years to come. This can be done by investing in strategic areas such as, road network, water reticulation, housing, health, tourism, agriculture, education and in manufacturing industries.

Konkola Copper Mines (KCM) is one of Zambia's largest copper mining companies. KCM is 51 per cent owned by Vedanta Resources, which has its headquarters in London. Dymond(2007) in the report 'underming development? Copper mining in Zambia' said, 'It is vital that Zambia is given a fairer share of the profits from its main natural resource to help combat crippling poverty in the country. Scotland's Aid Agency (SCIAF), Christian Aid, and Action for Southern Africa (ACTSA) in 2007 were calling for Vedanta management and UK investors to use their influence to make sure Zambia gets a fairer deal. Hitherto, evidence suggests that Zambia is drowning in poverty whilst a rich mining company is running away with its greatest natural resource.' ACTSA Campaigns Officer, Simon Chase said, 'Corporate accountability and social responsibility in the Copperbelt province of Zambia are being badly neglected. Zambian people are suffering at the hands of companies like Vedanta and this is their opportunity to implement real and positive change.'(Dymond, 2007).The operating divisions of Zambia Consolidated Copper Mines (ZCCM) prior to privatization sponsored and managed social recreation sports such as golf, football, cricket, rugby, bowling, tennis, squash, angling and boating among many other activities. Currently the sporting infrastructures have become dormant and acts as breeding grounds for various kinds of nefarious activities for youths due to plummeting levels of social responsibility by MNCs who have invested in the mining industry. Recreation facilities are no 
longer a priority as it used to be in the past, despite being a critical component of any vibrant society.

Dymond (2007) also focuses on KCM'semployment practices which have been described as 'draconian' with some sub-contracted skilled labourers claiming they are paid as little as £37 per month when it is estimated that the average Zambian family needs at least $£ 151$ a month to meet their basic needs. Concerns are also highlighted over the pollution arising from KCM's activities, and its effect on local communities. According to the Environmental Council of Zambia cited in Dymond's report, the 'grossly negligent' behaviour of 'KCM management' resulted in rivers used by local communities for drinking water being 'significantly polluted'. Environmental depletion has been the concomitant of mineral extraction in the Zambian mining towns with huge dumps and trenches being the common sights. The knock-on effects of the trenches are the breeding grounds for mosquitos and also pose a threat to children who play around these areas.

The report also calls on the government to make amendments to the Companies Act 2006 to ensure that UK businesses are held to account for the social and environmental impact of their activities in vulnerable developing countries (Dymond, 2007). Failure to do this will enable MNCs to continue exploiting the resources without tangible benefits for the locals.

\section{Niger Delta Case}

The Niger Delta region in Nigeria is another case in point of how MNCs have continued to reap resources without promoting CSR. This site experiences massive schism between the locals and MNCs as a result of pervasive environmental degradation. Aworawo (2013) notes that since the early 1970s, the oil producing enclave of the Niger Delta has been one of the most intensely polluted areas of the world. The pollution, coupled with severe environmental degradation, has largely been a consequence of the region's oil production and has made it difficult for the inhabitants of the Niger Delta to carry out their traditional economic activities of fishing and farming which are the major sources of livelihood, as local land and river systems have been too polluted to sustain such activities. This has caused extreme poverty and has also spawned violence. Some of the inhabitants have resorted to vandalise the pipeline as they are convinced that this is where the source of riches and livelihood lies. A common saying in the Niger Delta about any promise made by leaders at different levels is that it is in the pipeline,' which is another way of saying that it will never be fulfilled.Some petroleum pipeline vandals whowere arrested by security agents claimed that they broke the pipes to siphon petroleumproducts 
because the good life they had been promised by the government was 'in the pipeline' (Mbu, 2011 as cited in Aworawo, 2013).

Oil spillages in this region have been in existence for many years and the trend has not changed much throughout the first decade of the $21^{\text {st }}$ century. From 2000 to 2010, about a thousand cases of oil spillage were also recorded in Nigeria's oil producing enclave, resulting in extensive damage to the environment. This number of spills borders on absurd, and the impact of such carelessness and such devastation to the environment and the rural economy of the people of the Niger Delta cannot be overstated (Okere, 2013).Most of the oil activities from the oil extraction in Ogoniland are not shared by the Ogoni people and the perception of relative deprivation are ignited frequently in the Niger Delta area (Adeola, 2001). Of all oil revenues earned, only a small fraction (1.5 to 13 percent) by the central government since the mid-1980s have been allocated for the development of the area (Aworawo, 2012). Royal Dutch Shell and other associated MNCs (e.g., Agip Corp, Elf and Mobil) have taken over 30 billion dollars from Ogoniland leaving behind ecological ruins, destitutions, environmentally induced illness, and pre-mature deaths or shorter life expectancy among the people. Despite the magnitude of oil and petrochemical extraction activities in the area, there is a deplorable underdevelopment as reflected in the absence of basic infrastructure such as good roads, electricity, pipe-borne water, hospitals, and schools (Human Rights Watch, 1999). The lack of investments in social amenities and environmental protection explains their lack of interest in the area and the local people.

Given the severity of the problem in the area, efforts have been made to address the environmental problems that have beleaguered the area for many years. It remains an issue that cannot be continue to be given neither a 'blind eye nor a deaf ear' from many people across the globe.Nigeria's political leaders and executives of oil companies have agreed at various times to end gas flaring, which contributes tremendously to environmental pollution. Several deadlines have been set to end gas flaring, but none have been met, and different excuses have been given for why the targets have not been realized (The Guardian, 2011). Some of Nigeria's oil companies have complained about the high cost of installing the required equipment necessary to end gas flaring, but different government agencies and the people of the delta region have described such excuses as unsatisfactory (Aworawo, 2013). If pollution is to be addressed, such conditions should be sternly stated to the MNCs before commencing their operations.Governments' inaction to compel MNCs to oblige put them at the centre stage of colluding with MNCs to degrade the environment and causing health problems among the Ogoni people (Centre for Human Rights, 2001). Thus, there should be no compromise for non-adherence for laid 
down conditions for conducting oil exploration. As it is, the people of the area feel cheated and believe that they have robbed of their precious resources.

Obibi (1995) reports that 'even the illiterate and semi-illiterate are becoming aware of how oil wells are being depleted in the Ogoniland, how aquatic life has become extinct, how oil spillage is pushing the people to the brink of extinction, how the nights have been turned into day through continuous gas flaring, and how Royal Dutch Shell Company, Chevron and other oil MNCs have degraded the environment'. It can therefore be argued that with oil exploitation, usurpation of the locals from their native lands has been widespread to pave way for 'eluded development'. The locals' voice is no longer heard by both their governments and the MNCs. Neither the needs nor interests of the locals are recognized in today's globalised world. Environmental degradation and displacement of the locals have become accepted progenies of globalisation on which the MNCs have flourished their business deals. Then, were does this leave the local inhabitants, 'the owners of the land'? Who should protect them? At what expense? These are questions that need a critical understanding in order to avert the situation faced by those affected by the operations of MNCs.

\section{The Bosongo case}

With Bosongo Gold Limited, the case is similar to the already discussed. The communities of Prestea and Himan in Ghana had suffered adversely form the intensive blasting and activities of the company. Many inhabitants had their personal property damaged through blasting (Darimani 2005). Environmental destruction and pollution is a denial of basic human rights to healthy and safe environment. Therefore, MNCs need to consider this aspect seriously in their operation regardless of the area in which they operate. In least developed countries, environmental problems have escalated in recent years. This has been promulgated by the need to extract precious minerals by corporations as in the Prestai and Himan case. The communities bear the heaviest brunt which arises from the long term knock-oneffects of environmental destruction. On the $13^{\text {th }}$ June 2005, Himan and Prestea communities took to the streets to protest against Bosongo Gold Limited for lack of concern for environmental problems arising from their operation. They were dispersed by the military which was earlier deployed to protect the company and seven suffered gunshot injuries (Darimani, 2005).

Even though the communities had shown that they were suffering from the activities, especially blasting effects, the company continued to make rapid progress into the Prestia Township. The only football field was cleared to pave way for mining activities (Darimani,2005). Social amenities for MNCs are a secondary issue. The act of environmental destruction by 
MNCs at the expense of poor communities is noted by Renner (1996, p. 55) when he writes that, 'Their capacity to resist and defend their interests is extremely weak. These groups not only depend on marginal lands for subsistence, but they are also socially, economically, and politically disenfranchised. They are often too powerless to struggle for the preservation of natural systems upon which their livelihood and survival rest'. Because of their vulnerability to activities emanating from mining activities, the environment from which they rely to make a living such as subsistence farming, wild fruit and fire wood gathering has been substantially degraded.

\section{Sidoarjo case}

The environmental tragedy which happened on $29^{\text {th }}$ May2006, on the Indonesian island of Sidoarjo shocked many from around the globe and is probably one of the greatest catastrophes in living memory. It is one of the disastersthat has been covered extensively both locally and internationally, on Java Post, The New York Times,International Herald Tribune, BBC, Asia Times Online, and even the National Geographic Channel.The Indonesian corporationPT Lapindo Brantas, alongside other corporations has been exploring oil and gas for years in Indonesia. According to Friends of the Earth International report (2007), the gas well had reached 3,000 meters when mudflow started gushing and is still flowing today. According to Davies et al. (2011) it is expected that the flow will continue for the next 25 to 30 years. The suspected cause is most likely that it occurred as a consequence of Lapindo's failure to install a casing around the well to the levels required under Indonesian mining regulation. This has resulted in massive environmental degradation and most of the infrastructure, such as houses, schools, hospitals, roads has been inundated. This led to thousand deaths of poultry, goats, cattle and a host of other animals, including crops. Both economic and social activities have tremendously been affected in the area.'It is reported that the number of displaced people is expected to be 50,000’ (New York Times, 2006). Further still as Jakarta Post 2007 notes, 'the number of flooded villages stands at 11 with 3,500 families displaced, 350 hectares of farm land and 23 schools buried' (Friends of the Earth International 2007, p. 4).

Despite the predicament the local people found themselves as a result of the exploratory search for natural gas deposits, Lapindo was reluctant to compensate the victims of the floods who lost entirely everything. As the Jakarta Post, 8 June 2007 notes, 'the Indonesian President has asked Lapindo to compensate all the 11 villages while Lapindo claims the compensation costsare too high' (Friends of the Earth International 2007, p. 4). 'The company was ready only to pay upon the victim's presentation of a 
resident land ownership document, a document which most victims lost in the floods along with other belongings' (http://mudflowsidoarjo.110mb.com/index.htm accessed on 26/03/2016). If CSR was on their agenda, surely the suffering families could have been compensated to ease the torment incurred in this tragic incident which was not of their making, rather caused the company extracting their resources. Greenpeace Southeast Asia couches the activities of MNCs in this catastrophe as follows: 'The Lapindo mudflow disaster stands out as an iconic example of a corporate crime, demonstrating how irresponsible activities by big business continue to wreak havoc on the environment and people's lives. Corporations are rewarded with overgenerous opportunities and rights to profit from the exploitation of the environment. At the first sign of trouble, they tend to take flight leaving their legacies of suffering and degradation behind. The Lapindo disaster is a classic example of this trend' (Greenpeace, 2006).

The mud poses a health hazard to the people as it contains toxic materials that may have severe consequences. The mud also contains Phenol, at concentration exceeding the maximum residual limit. Phenol is toxic to fish and aquatic vegetation, not to mention human health (Ibid). The deleterious effects of these activities on both fauna and flora life are farreaching including human beings.As early as August, two months after the tragic incident, the environmental group WALHI (Wahana Linkungan Hidup Indonesia) reported that Sidoarjo hospital had as many as 1,500 patients registered as affected by gas (hydrogen sulphide-H2S). Symptoms included dizziness, breathlessness, breathing difficult and irritation. Many others had diarrhea (Friend of the Earth, 2007). The acts of MNCs can be termed to be adverse on the environment and the people, as the area has been desolated. The environment is less likely to regenerate and the landscape has been severely altered. The Sidoarjo mud volcanic case further buttresses the inclination of MNCs to generate more wealth and increase their might with less attention on the communities and environment where they do business. Kelleher (2005) posits that, 'MNCs have enormous financial power which they can choose to exercise positively and make a substantial contribution to society. However, many companies still believe that they exist purely to maximise shareholder returns and that the end justifies the means' (p. 65). In other words CSR is something they can easily put on their agenda and contribute positively to the development of the communities they operate. However, in this globalised world, profits seem to supersede environmental protection and investing in human capital. 


\section{Recommendations}

- A comprehensive social policy should be a requirement for MNCs. This will compel them to develop clear understanding of the social context of their areas of operation. It will also compel MNCs to demonstrate that their presence in a community and country really does provide value to realise both social and economic development to the local community and national economy in which they operate

- Governments should develop mechanisms for MNCs to detect tax avoidance as means of ploughing back to the communities where they operate. In addition, mechanisms for imposing sanctions on companies that deviate from the stipulated guidelines should be developed. These mechanisms should be availed to the publicfor easy accessibility to all citizens and the local communities.

- Governments should establish legal norms to hold MNCs accountable for human rights violations. Perhaps, one of the approaches would be to establish mechanisms of enforcing established treaties that specify the human rights obligations of MNCs.

\section{Conclusion}

The paper has argued the link between environmental problems and the operations of MNCs in various parts of the world. It has brought to the limelight some factors that have further promulgated the destruction of the environment by MNCs, which include inter alia profit maximization, lack of stringent environmental laws and policies in developing countries, the support by multilateral institutions such as the World Bank, IMF and their host countries. The extent to which the communities are being pushed to marginal barren land unfit for habitation without receiving any benefit from their own resources has also been the focus of the paper. The financial capacity of MNCs can undoubtedly make them contribute significantly to poverty alleviation, promote human rights, environmental protection and invest in human capital in areas where they operate. However, given their need for profit maximization, the possibility that environmental destruction will be halted and MNCs assume full corporate social responsibility seems murky at the moment.

\section{References:}

Addo, M.K. (1999) Human Rights and Transnational Corporations--an Introduction, in Human Rights Standards and the Responsibility of Transnational Corporations.

Adeola, F. (2001) Environmental Injustice and Human Rights Abuse: The States, MNCs, and Represssion of Minority Groups in the World System, Human Ecology Review, Vol. 8, No. 1, pp. 39-59 
Aworawo, D. (2012). Divisive dividing: Revenue allocation and unrest in Nigeria since the late colonial period, Histotia Actual Online. 28, pp. 17-48. Aworawo, D. (2013) Deprivation and Resistance: Environmental Crisis, Political Action, and Conflict Resolution in the Niger Delta since the 1980s, Journal of International and Global Studies, Vol 4. No. 2, pp. 52-70

Bosshard, P. (2008) 'China's Environmental Footprint in Africa: China in Africa Policy'. China in Africa Project of the SA Institute of International Affairs (SAIIA), No 3.

Business Dictionary (2016) available at http://www.businessdictionary.com/definition/multinational-corporationMNC.html accessed on 26/03/2016).

Center for Human Rights (2001) available at http://www.chr.up.ac.za/index.php/browse-by-subject/410-nigeria-socialand-economic-rights-action-centre-serac-and-another-v-ni accessed on 23/05/2016

Cissé, D., Grimm, S. and Nölke, A.(2014) State-Directed Multi-National Enterprises and Transnational Governance: Chinese Investments in Africa, Corporate Responsibility and Sustainability Norms, Stellenbosch: Centre for Chinese Studies

Clark, C. (1986) 'Sustainable Development of the Biosphere: Themes for a Research plan', in Clark, C. and Mann, E. (eds.) (1986) Sustainable Development of the Biosphere, Cambridge: Cambridge University Press.

Cowe, R. (2001) Investing in Social Responsibility; Risks and Opportunities. London: Association of British Insurers.

Darimani, A. (2005), Impact of Activities of Canadian Mining Companies in Africa, Ghana: The World Network- Africa Secretariat

Dauvergne, P. (1997) Shadows in the Forest: Japan and the Politics of Timber in Southeast Asia, Cambridge: Mass MIT Press

Davies, R.J., Mathias, S.A., Swarbrick, R.E. and Tingay, M.J. (2011) Probabilistic longevity estimate for the LUSI mud volcano, East Java. Journal of Geological Society 168: pp. 517-523.

Dobscha, S. and Ozanne, J. (2001), AnEcofeminist of Environmentally Sensitive Women Using Qualitative Methodology: The Emancipatory Potential of an Ecological Life, Journal of Public Policy and Marketing Vol.20, No. 2, pp. 201-214

Dymond, A. (2007) undermining development? Copper Mining in Zambia, London :ACTSA, Christain Aid, Scotlands Aid Agency

Fielding, N. (2004) Getting the most from archived qualitative data: Epistemological, practical and professional obstacles. International Journal of Social Research Methodology Vol. 7, No. 1, pp. 97-104. 
Financing Finance (2016) available at http://www.facingfinance.org/en/2016/02/collum-coal-mining-collapsed-tunnels-destroyzambian-village/ accessed on 19/05/2016

Friends of the Earth International (2007) LapindoBrantas and the Mud Volcano Sidoarjo, Indonesia, June 15

Glaser, B. (1963) The use of secondary analysis by the independent researcher. The American Behavioural Scientist(6),pp. 11-14.

Greenpeace (2003), Campaign Against Global Warming

Greenpeace (2006)Mudflow Slipping Beyond Control: Government Must Hold Lapindo, Affiliates and Owners Accountable. Press release, September 20. Greenpeace, Southeast Asia. Available at http://www.greenpeace.org/seasia/en/press/release/mudflow-slippingbeyond-contro accessed on 10/05/2016

Gurr, T. R. (1993), Why Minorities Rebel: A global analysis of communal mobilization and conflict since 1945, International Political Science Review (14), pp. 161-201

Harper, L.C. (1996), Environment and Society: Human Perspectives on Environmental Issues. New Jersey: Prentice Hall.

Heaton, J. (1998) Secondary analysis of qualitative data. Social Research Update (22), Department of Sociology, University of Surrey, Online journal available at: http://www.soc.surrey. ac.uk/sru/SRU22.html accessed on $15 / 05 / 2016$

Hinds, P.S., Vogel, R. J. and Clarke-Steffen, L. (1997) The possibilities and pitfalls of doing a secondary analysis of a qualitative dataset. Qualitative Health Research, Vol. 7, No. 3,pp. 408-424.

http://mudflow-sidoarjo.110mb.com/index.htm accessed on 27/03/2016 http://www.whirledbank.org/ourwords/summers.html accessed on 27/03/2016

Human Rights Watch (1999) The price of Oil: Corporate Responsibility and Human Rights Violation in Nigeria's Oil Producing Communities, New York: Human Rights Watch

Johnson, J.,Pecquet, G., and Taylor, L. (2007) Potential Gains from Trade in Dirty Industries: Revisiting Lawrence Summers' Memo, Cato Journal, Vol. 27, No. 3, pp. 397-410

Kelleher, A. (2005) Corporations and Global Governance: A Multi-Cultural Futures Perspective, Journal of Future Studies, August, Vol.10, No 1, pp 4962

Korten, D. C., (1997), 'Getting Power back to the People', The Futurist, Vol.31, No 3, pp. 20-21

Korten, D. C., (2001) When Corporations Rule the World, $2^{\text {nd }}$ ed. USA: Koehler 
Mol, A.P.J., (2011) 'China's Ascent and Africa’s Environment', Global Environmental Change 21, pp. 785-794.

New York Times.(2006) New York, 6 October

Obibi, C. (1995), A people Divided by Death, The Guardian, November 28, 11

Okere, R. (2013). 'Oil Spills in Nigeria: Where the Law Doesn't Rule'. The Guardian, Lagos, 6 February.

Petroleum News.(1998). Lagos, April.

Renner, M. (1996) Fighting for Survival: Environmental Decline, Social Conflict, and the New Age of Insecurity. New York: W.W. Norton and Company.

Scherr, S. J. (1987), Hazardous Exports: US and international policy development, in Pearson C. S. (ed.), Multinational Corporations, Environment, and the Third World, 129-148. Durham: Duke University.

Suzuki, D. and Dressel, H. (1999) From Naked Apes to Superspecies: A Personal Pespective on Humanity and the Global Eco-crisis. St Leonard: Allen \&Unwin.

Tan, J. and Wang, L. (2011) 'MNC Strategic Responses to Ethical Pressure: An Institutional Logic Perspective', Journal of Business Ethnics, Vol. 98 No. 3, pp. 373-390. 